\title{
STRUCTURAL CHANGES OF FARMER'S FARMS: CASE STUDY OF LITHUANIA
}

Jurgita ZALECKIENÉ, Business and Rural Development Management Institute, Faculty of Economics and Management, Aleksandras Stulginskis University, Universiteto str. 10, 53361, Akademija, Kaunas dstr., jurgita.zaleckiene@ gmail.com

Due to historical circumstances, the development of Lithuanian commercial farmer's farms is slow; however, farmer's farms are very important to the vitality of rural areas while developing agricultural commodities and goods. The purpose of this article - to analyze the structural changes in farmer's farms and present the directions of future development. Structural changes in Lithuanian farmer's farms during the 2005 - 2015 timeframe were analyzed while looking at the diagnostic indicators, which are the following: the number of farmer's farms, the structure of farmer's farms according to their size, the activity units of farmer's farms, age of farmers, farmer's farms sources of income. In order to study the statistical data, methods of systemization, logical analysis and generalization were applied. The analysis of the statistical data suggests that the following structural changes are taking place in Lithuanian farmer's farms: the number of registered farmer's farms increases and the farmers' are getting younger. One of the most significant factors causing the structural changes in holdings - the EU financial support for the agricultural development and the changing customer demands. More and more often rural areas perform residential function and new living areas are developed.

There is a predominance of the small farms (up to 10 hectares). This is mainly a result of the reform in agricultural sector at the end of 20th century. Many small agricultural holdings were established due to this reform. However, significant changes occur while choosing and/or combining the activity units of the farm: the number of farms specializing in crops increases, the number of the holdings focusing on livestock and combined farming (crops and livestock) is declining; also, farmer's farms with diversified income or the activity units grow in number. Limited opportunities to intensify agricultural production in small farmer's farms caused the fact that activities or income were diversified. The model of family farm remains; however, the relation between activity and the usage of family's labour in farm activity changes.

Keywords: factors that determine the changes, farmer's farms, structural changes.

\section{INTRODUCTION}

Agricultural business organizations differ according to their legal and organizational aspects. In the European Union (hereinafter referred to as EU) and many other countries around the world, farmers' farms represent a significant part of agricultural organizations. Farmer's farms operate in dynamic environment; consequently, the changes in agricultural policy (Darnhofer, Lamine et al, 2016; Rizov, 2005; Dužinskas, Ratkevičienè et al, 2007) and consumer demands (Scala, Noventa et al, 2017), the technological progress (Bowler, Clark et al, 1996), the increased focus on environmental protection (Dabkiene, 2016; Menozzi, D., Fioravanzi et al, 2015), the fluctuations in purchase price of agricultural products (Zimmermann, Heckelei et al, 2009) and many other factors influence the traditions of consumption and markets of agricultural products as well as the producers of agricultural products - the farmers. They are forced to adapt to changes in the production and realization of goods while implementing the requirements of safety and quality regarding the production of goods. According to the scholars (Meer, van Huylenbroeck et al, 2005, Rizov, 2005; Dužinskas, Ratkevičienè et al, 2007), one of the most significant reasons causing structural change in farmer's farms is internal, not external, environment - the farming does not ensure the sufficient level of living standard. This is the result of many subjective and objective factors; for instance, the small farm (small agricultural area), the high number of farm members, the small scale of farmers' entrepreneurship, the great functional dependence on climatic conditions. This situation and changes in external and internal environment of farmer's farm result in a need for farmers to change themselves and the situation while changing the activity of the farm. Changes directed to the development of farmer's farms lead to the development of farmer's resistance and competitiveness. Research issue - what kind of structural changes are taking part in Lithuanian farmer's farms?

The purpose of the article - to analyze structural changes in farmer's farms and present the directions of future development.

\section{RESEARCH METHODS}

Scholars (Gao, Zaang et al, 2017, Dreby, Jung et al, 2017; Hansson, Ferguson et al, 2013; Domenico, Miller, 2012; Poviliūnas, 2008; Treinys, 2006) analyze the farmer's farms in the context of family farms while highlighting the family

Copyright (C) 2017 The Authors. Published by Aleksandras Stulginskis University. This is an open-access article distributed under the terms of the Creative Commons Attribution License (CC-BY 4.0), which permits unrestricted use, distribution, and reproduction in any medium, provided the original author and source are credited. 
nature of farms. Often discussions occur while identifying whether it is family farm or farmer's farms; however, it is agreed that the property and its management depends on family members and most of the work is done by the family members. In Lithuania, there are two major groups of the agricultural subjects: farms of natural persons and farms of legal entities. In the academic researches and publications of statistical information the farms of natural persons are identified as farmer's farms. Object of the research - farmer's farm - agricultural organization of the farmer or his/her family registered in Register of Farmers' Agricultural Holdings and legally represented by the farmer or his/her family.

In various academic researches (Espinosa, Gocht et al, 2016; Huber, Flury et al, 2015; Zimmermann, Heckelei et al, 2009; Kazakevičius, 2007) the structural changes in farmer's farms are analyzed after taking into consideration different diagnostic quantitative and qualitative indicators. These indicators can be described by the following diagnostic factors: the change of number of farmer's farms, the average size of farmer's farm (hectares), the activity units of the farmer's farm, the effectiveness of farmer's farm, the income sources of farmer's farm, the farming purposes, age and education of farmers, farmers' attitude towards the farming etc.

The lack of information and the diversity of data presented in different information sources resulted in limitation of the research and presupposed the choice of the main selection criteria for the research - the measurement of diagnostic indicator. Diagnostic indicators analyzed in this article are presented in the Table 1.

Table 1. The characteristics of diagnostic indicators

\begin{tabular}{|l|l|l|}
\hline \multicolumn{1}{|c|}{ Diagnostic indicator } & \multicolumn{1}{|c|}{ Scope of diagnostic indicator } & \multicolumn{1}{c|}{ Information source } \\
\hline Number of farmer's farms & Total number of registered farmers' farms. & $\begin{array}{l}\text { Agriculture and Food sector in Lithuania } \\
2015,2010,2005 . \\
\text { ithuanian Agriculture: Facts\&Figures. } \\
\text { Semiannual Statistical report. }\end{array}$ \\
\hline Area per farmer's farms & $\begin{array}{l}\text { Holdings are divided into groups according to } \\
\text { their area (in hectares): <10 ha, 10-50 ha, 50-100 } \\
\text { ha, }>100 \text { ha. }\end{array}$ & $\begin{array}{l}\text { Agriculture and Food sector in Lithuania } \\
2015,2010,2005 .\end{array}$ \\
\hline Average area per farmer's farm & The average area per holding, in hectares. & \\
\hline Farmer's farms activities units & $\begin{array}{l}\text { Activities developed in holding: agricultural } \\
\text { activities (for example, crops, livestock, } \\
\text { beekeeping, poultry) and not agricultural } \\
\text { activities (rural tourism, crafts, forestry business, } \\
\text { etc.). }\end{array}$ & $\begin{array}{l}\text { Lithuanian Agriculture: Facts\&Figures. } \\
\text { Semiannual Statistical report. }\end{array}$ \\
\hline Number of organic farmer's farm & $\begin{array}{l}\text { Number of organic farmer's farms and certified } \\
\text { area, ha. }\end{array}$ & $\begin{array}{l}\text { Agriculture and Food sector in Lithuania } \\
\text { 2015, 2010, 2005. }\end{array}$ \\
\hline Age of farmers & $\begin{array}{l}\text { Holdings are divided into groups according to } \\
\text { and older. }\end{array}$ & $\begin{array}{l}\text { Lithuanian Agriculture: Facts\&Figures. } \\
\text { Semiannual Statistical report. }\end{array}$ \\
\hline Farmers' farm sources of income & $\begin{array}{l}\text { Incomes not from farm activities (salaries etc.). } \\
\text { Incomes from other farm activities (not } \\
\text { agricultural). }\end{array}$ & FADN survey results 2015, 2010, 2005. \\
\hline
\end{tabular}

The investigated period - 2005-2015. Research methods: analysis and synthesis of scientific literature, comparative analysis of statistical data; statistical data is processed by the methods of systemization, logical analysis and generalization.

\section{RESEARCH RESULTS}

Conventional farming in Lithuania. Lithuanian farmers started to establish their agricultural holdings in 1989 (Grakauskas, 2009; Kazakevičius, 2007). The development of Lithuanian farmer's farms was complicated because reforms did not facilitate rural entrepreneurship. Land reform was introduced in 1990 and it aimed to return land or remaining property to the former owners or their inheritors. The ways how to save production capacity and agricultural productivity inherited from collective farms were not analyzed and it was not discussed how to facilitate newly developed farms. Both land reform and farming relied more on emotional aspect rather than on economic calculations (Poviliūnas, 2008).

In the structure of postreform organizations dominated small farmer's farms of low economic viability (Jurkènaite், 2012) and capacity regarding the investments (Poviliūnas, 2008, 200; Treinys, 2001). Researchers (Kazakevičius, 2007) state that the purpose of farming in small holdings is not the profit. Farmers seek to supply their families with goods produced by themselves and do not abandon land, which is a value. This shows that commercial farms ${ }^{1}$ are developed slowly. Scholars suggest that entrepreneurship is linked to innovations and risk-taking (Morgan, Marsden et al, 2010; Mooney, Defenderfer et al, 2010). Due to such historical circumstances related to farmer's farms as the lengthy period of command economy, relatively short experience of independent farming etc., there is a lack of market infrastructure, entrepreneurship is disappearing, farmers depend too much on external measures for development of farm (for example, financial support) in Lithuania (Treinys, 2001). Author's previous researchers suggest the idea that many farmers are not

\footnotetext{
${ }^{1}$ Commercial farmer's farm - farmer's farm, where the farmer and his family provide work and income from farm activities.
} 
able to evaluate and use knowledge because of the lack of entrepreneurial skills, overestimation of acquired skills and qualification and a vague cooperation with other farmers (more in Zaleckiené, 2008). Furthermore, D. Vidickiené, R. Melnikiené et al, 2013, Matekoniené, Kozlovskaja et al, 2011) determined that the majority of farmers does not analyze farming activities and competitors; also, they do not plan their activities, do not search for alternatives for the development of farming activities, do not perform SWOT analysis and do not investigate consumer demands. These methods are hardly understood and rarely applied by the farmers (Vidickienè, Melnikienè et al, 2013). On one hand, this situation resulted because of historical peculiarities - a significant part of the farmers entered into agricultural sector form other areas without proper education and with poor practical experience. However, due to active agricultural policy, farmers did not have to care about their competitive advantage or cardinal reorganization of farming activities in their holdings. This suggests that characteristics describing rural entrepreneurship (for example, independence, formulation and realization of new ideas, development of cooperation and etc.) are still in initial stage.

However, the farming remains still popular because of such factors as limited possibilities for the development of nonagricultural activities in rural area, EU structural support for agriculture and etc. (Vidickiené, Melnikienė, 2014; Raupelyté, Liesionis, 2008). Urban development, changes in life and work styles provide new opportunities for the development of farmers' agricultural holdings. According to J. Jasaitis (2009), the diversification of farmers' agricultural holdings promotes the demand of goods and services "regarding the concept of new house, which is still being developed". Because of informatics and communicational technologies, the workplace often is not centralized and it moves to the house of employees (Vidickienè, Melnikienè, 2014).

Changes in Lithuanian farmer's farms during the 2005-2015 timeframe. The analysis of collected statistical data (Table 2) suggests that the following structural changes occur in farmer's farms: the number of registered farmer's farms grows.

Table 2. Characteristics of Lithuanian farmer's farms in 2005-2015.

\begin{tabular}{|c|c|c|c|c|c|}
\hline & $\begin{array}{c}\text { Units of } \\
\text { Measurement }\end{array}$ & 2005 & 2010 & 2015 & $\begin{array}{c}\text { Change in } 2015 \\
\text { compared to } \\
2005, \%\end{array}$ \\
\hline Number of registered farmer's farms & Thousand & 85.9 & 108.7 & 122.5 & 42.6 \\
\hline Average area per registered farmer's farm & $\mathrm{Ha}$ & 12.2 & 10.8 & 9.4 & -22.9 \\
\hline $\begin{array}{l}\text { Structure of farmer's farm per area (ha) } \\
<10 \\
10-50 \\
50-100 \\
>100\end{array}$ & Percent & $\begin{array}{c}47.8 \\
44.4 \\
4.9 \\
2.9\end{array}$ & $\begin{array}{l}71 \\
25 \\
2 \\
2\end{array}$ & $\begin{array}{l}75 \\
20 \\
3 \\
2\end{array}$ & $\mathrm{X}$ \\
\hline $\begin{array}{l}\text { Structure of farmer's farms in relation to the farmers' age } \\
<40 \text { years } \\
40-65 \text { years } \\
>65 \text { years }\end{array}$ & Percent & $\begin{array}{l}16 \\
40 \\
44 \\
\end{array}$ & $\begin{array}{l}19 \\
43 \\
38 \\
\end{array}$ & $\begin{array}{l}17 \\
47 \\
36 \\
\end{array}$ & $\mathrm{X}$ \\
\hline \multicolumn{6}{|l|}{ Structure of farmer's farms by main type of farming } \\
\hline $\begin{array}{l}\text { Cropping } \\
\text { Livestock } \\
\text { Crops and livestock combined } \\
\text { Other }\end{array}$ & Percent & $\begin{array}{l}21.9 \\
44.9 \\
22.4 \\
10.8\end{array}$ & $\begin{array}{c}46.2 \\
27.6 \\
15.1 \\
11\end{array}$ & $\begin{array}{l}46.1 \\
24.3 \\
14.7 \\
14.9\end{array}$ & $\mathrm{X}$ \\
\hline Number of organic farmer's farm & Number & 1811 & 2668 & 2672 & 47.5 \\
\hline Certified area & Thousand ha & 69.4 & 149.1 & 220.2 & 217.3 \\
\hline Income of farmer's farms from nonagricultural activities & $\begin{array}{c}\text { EUR/ per } \\
\text { year }\end{array}$ & 335 & 674 & 798 & 138.2 \\
\hline Income of farmer's farms from no farm activities (salary) & $\begin{array}{c}\text { EUR/ per } \\
\text { year }\end{array}$ & 1292 & 4172 & 6154 & 376.3 \\
\hline
\end{tabular}

Source: prepared by the author.

These changes mainly take place because of legal framework - only those farms which are registered and operating can use financial support, enter into agreements with suppliers or collectors of agricultural products and represent farm in other ways. The environment of farming influenced by the legal means contribute to the farmers' attitude towards farming: the change from "farming as a lifestyle" to "farming as a business". This change was also caused by the younger farmers - a part of the farmers of 65 years or older decreased by 8 percent. CAP support model in Lithuania increases the attractiveness of farming. According to the data of the National Paying Agency under the Ministry of Agriculture of the Republic of Lithuania (hereinafter referred to as NPA), during the 2007-2013 timeframe, 450 farms averagely were established annually by the young farmers. A significant number of older farmers, who owned farms as family businesses that were developed naturally due to rural lifestyle and not because of motivated purpose, used the EU support measure and retired from the production of agricultural goods ${ }^{2}$.

\footnotetext{
${ }^{2}$ According to the NPA, during the 2007-2013 timeframe, 123.6 thousand applications were approved under the measure „Early Retirement from Agricultural Production Activities“ (Lietuvos kaimo..., 2016).
} 
However, the changes mentioned previously did not influence the growth of farms - significantly - small (up to 10 ha) farmer's farms are dominant. This is mainly a result of the reform in agricultural sector at the end of $20^{\text {th }}$ century. Many small agricultural holdings were established due to this reform. Land, financial and material resources are limited in this type of farms and this complicates the development opportunities for their modernization and expansion of agricultural area. On the other hand, various restrictions were established regarding the acquisition of agricultural land (Žemès rinkos...), consequently, the demand of agricultural land decreased in the market. The small farmer's farms do not contribute significantly to the development of commercial goods; however, these farms are important developers of such commodities as viability of rural areas, protection of natural resources and biological diversity, landscape and etc.

During the investigated period, the significant changes regarding the development direction of activities in farms occurred. These changes can be described by the structural changes related to development direction and the shift of income from nonagricultural activities and income received from not farm activities. First of all, limited opportunities to intensify agricultural production in small farmer's farms caused the fact that activities or income were diversified. More and more farmer's farms diversify activities, for example, farmers start other activities together with conventional farming (for instance, production of food, timber processing, manufacture of wood articles, services of rural tourism and etc.). Previous researchers of the author (more in Zaleckienè, 2015; Čaplikas, Rutkauskaitè, 2006) suggest the idea that the main purposes and motives for diversification is to use possible opportunities provided by the markets, divide the risk of agricultural business and to increase/stabilize income from farm. Secondly, since 2004 the support for farmers has been linked with agricultural area; consequently, the number of farms specializing in crops is decreasing whereas the number of farms specializing in livestock is decreasing. The number of farmer's farms focusing on livestock, specifically, farms directed to milk production decreased by 3.14 times. Farmer's farms where up to 19 dairy cows are kept decreased from 180 thousand in 2015 to 51.1 thousand in 2015. The number of dairy cows decreased by $35 \%$ during the period considered. This was mostly influenced by the volatility of raw milk purchase prices ${ }^{3}$ and the retirement of farmers from commercial agricultural production.

During the investigated timeframe, the number of organic farmers' farms increased. When comparing 2015 with 2005 the number of organic holdings rise 1.5 times and certified area - more than 3 times. These changes were mainly caused by the changing customer demands and the development of suburban areas. More and more often rural areas perform residential function and new living areas are developed. In areas, which were considered to be rural, the number of citizens, who have nothing in common with agriculture, increases. However, these people have a clear understanding about nature, healthy lifestyle, ecology. The demand for food products and various services rises in this type of regions. This causes not only the development of organic farmer's farms but also the diversification of farm activities.

To sum up, it can be stated that the structural changes in farmer's farms result in the remaining family farm model: in 2005, 94\% of employees in farmers' holdings were farmers themselves and their family members. In 2015 - 84\% (Ūkiu veiklos..., 2006, 2016). However, the ratio between the activity and the usage of family labour changes. Farmers of small holdings tend to diversify farm activities or income, whereas bigger farms specialize and intensify agricultural production. Most likely these tendencies will remain in the future. The growing consumers' attention to the local food develops conditions to produce differentiated agricultural products and to diversify farm activity.

\section{CONCLUSION}

The development of farmer's farms covers several periods in Lithuania. One of the most significant factors causing the structural changes in holdings - the EU financial support for the agricultural development and the changing customer demands.

The family farm model remains in Lithuania. Farmers of small agricultural holdings tend more to diversify farm activity or income and bigger farms - specializes in agricultural production from crops.

\section{REFERENCES}

1. Bowler, I., Clark, G., Crockett, A., Ilbery, B., Shaw, A. 1996. The Development of Alternative Farm Enterprises: A Study of Family Labour Farm in the Northern Pennines of England. Journal of Rural Studies, Vol. 3, pp. 285-295. https://doi.org/10.1016/0743$\underline{0167(96) 00015-0}$

2. Čaplikas, J., Rutkauskaite, J. 2006. Diversification Types of Agricultural Business Organizations Activity and Factors Determining them. Proceedings of the International Scientific Conference "Research for Rural Development 2006", Book 1, pp. 162-168, Latvia University of Agriculture.

3. Dabkiene, V. 2016. An analysis of Biodiversity Oo Lithuanian Family Farms In Scientific Papers Series Management, Economic Engineering in Agriculture and Rural Development, Vol. 16, Iss. 3, pp. 97-102 .

4. Darnhofer, I., Lamine, C., Strauss, A., Navarrete, M. 2016. The resilience of family farms: Towards a relational approach. Journal of Rural Studies, Vol. 44, pp. 111-122 . https://doi.org/10.1016/j.jrurstud.2016.01.013

5. Domineco, M. L., Miller, G. 2012. Farming and tourism enterprise: Experiential authenticity in the diversification of independent small-scale family farming. Tourism Management, Vol. 33, Iss. 2, pp. 285-294. https://doi.org/10.1016/j.tourman.2011.03.007

6. Dreby, J., Jung, G., Sullivan, R. 2017. At the nexus of work and family: Family farms in upstate New York. Journal of Rural Studies, Vol. 49, pp. 151-161. https://doi.org/10.1016/j.jrurstud.2016.12.001

\footnotetext{
${ }^{3}$ Purchase price of milk in 2005 was 164 Eur/t; 2010-208 Eur/t; 2012-216 Eur/t, 2013-263 Eur/t; 2015-178 Eur/t. (Lietuvos žemès..., 2006, 2011, 2016).
} 
7. Dužinskas, R., Ratkevičienè, V., Jasaitis, J. 2007. Ūkinès veiklos įvairovès skatinimas kaimiškosiose vietovèse: lūkesčiai ir galimybès (Promoting Diversity in Rural Areas: Expectations and Opportunities). Žemès ūkio mokslai (Agricultural Sciences), No. 14 (priedas), pp. 27-34. (In Lithuanian)

8. Espinosa, M., Gocht, A., Heckelei, T., Paloma, S. G. 2016. Incorporating farm structural change in models assessing the Common Agricultural Policy: an application in the CAPRI farm type model. Journal of Policy Modeling, Vol. 38, pp. 1040-1059 . https://doi.org/10.1016/j.jpolmod.2016.03.005

9. Gao, Y., Zhang, X., Wu, L., Yin, S., Lu, J. 2017. Resource basis, ecosystem and grouwth of grain family farm in China: based on rough set theory and hierarchical linear model. Agricultural Systems 154, pp. 157-167 . https://doi.org/10.1016/j.agsy.2017.03.013

10. Grakauskas, E. 2009. Agrarinè teisè (Agrarian Law). Vilniaus informacijos centras, Vilnius. [In Lithuanian]

11. Hansson, H., Ferguson, R., Olofson, Ch., Rantamäki-Lahtinen, L. 2013. Farmers` motives for diversifying their farm business The influence of family. Journal of Rural Studies, Vol. 32, pp. 240-250 . https://doi.org/10.1016/j.jrurstud.2013.07.002

12. Huber, R., Flury, Ch., Finger, R. 2015. Factors affecting farm growth intentions of family farms in mountain regions: Empirical evidence for Central Switzerland. Land Use Policy, Vol. 47, pp. 188-197. https://doi.org/10.1016/j.landusepol.2015.04.006

13. Jasaitis, J. 2008. Neurbanizuotu teritorijų plètros administravimas poindustrinejje visuomeneje (Public Administration of Rural Areas Development in the Post-Industrial Society) Ekonomika ir vadyba: aktualijos ir perspektyvos (Economics and management: current Issues and Perspectives), Vol. 1, No. 1), pp. 47-63. [In Lithuanian]

14. Jurkėnaitè, N. 2012. Lietuvos ūkininkų ūkių ekonominio gyvybingumo palyginamoji analizè (Comparative Analysis of Lithuanian Family farms‘ economic Viability). Žemès ūkio mokslai (Agricultural Sciences), No. 4, pp. 288-298. [In Lithuanian]

15. Kazakevičius, Z. 2007. Žemès ūkio subjektų struktūriniai ir veiklos pokyčiai (Structural and practical changes of Agricultural Entities). Management theory and studies for rural business and in-frastructure development, Vol. 15(4), pp. 42-49. [In Lithuanian]

16. Lietuvos žemès ir maisto ūkis 2005 (Agriculture and Food sector in Lithuania 2005). 2006. Autoriu kolektyvas: R. Melnikienė vadovė...[et al.]. Vilnius: Lietuvos agrarinès ekonomikos institutas. [In Lithuanian]

17. Lietuvos žemès ir maisto ūkis 2010 (Agriculture and Food sector in Lithuania 2010). 2011. Autorių kolektyvas: R. Melnikienė vadovė...[et al.]. Vilnius: Lietuvos agrarinès ekonomikos institutas. [In Lithuanian]

18. Lietuvos žemès ir maisto ūkis 2015 (Agriculture and Food sector in Lithuania 2015). 2016. Autorių kolektyvas: R. Melnikienė vadove....[et. Al]. Vilnius: Lietuvos agrarinès ekonomikos institutas. [In Lithuanian]

19. Lithuanian Agriculture: Facts\&Figures. Semiannual Statistical report. SE Agrucultural Information \& rural Business Centre. Available at https://www.vic.lt/?mid=75 (Accessed on 10/08/2017) [In Lithuanian]

20. Matekonienè, J., Kozlovskaja, A., Kuliešis, G., Lukošiūtè, I. 2011. Lietuvos žemès ūkio subjektų organizacinès elgsenos verslumui tyrimas (Research of the Impact of the Organizational Behaviour of Lithuanian Agricultural Enterprises on Entrepreneurship of the Employees). Management theory and studies for rural business and in-frastructure development, Vol. 4(28), pp. 83-90. [In Lithuanian]

21. Meert, H., van Huylenbroeck, G., Vernimmen, T., Bourgeois, M., van Hecke, E. 2005. Farm household survival strategies and diversification on marginals farms. Journal of Rural Studies, Vol. 21, pp. 81-97. https://doi.org/10.1016/j.jrurstud.2004.08.007

22. Menozzi, D., Fioravanzi, M., Donati, M., 2015, Farmer's motivation to adopt sustainable agricultural practices, Bio-based and Applied Economics, Vol. 4(2), pp. 125-147.

23. Poviliūnas, A. 2008. Lietuvos žemès ūkio grịzimas ị rinkos santykius ir ūkininkijos ekonominè raida (Reversion of the Lithuanian Agriculture into Market Relations and the Economic Development of Farming). Lietuvos agrarinès ekonomikos institutas. Vilnius. [In Lithuanian]

24.Raupelyte, L.; Liesionis, V. 2008. Ūkininko ūkio, kaip verslo organizacijos, veiklos ir valdymo ypatumai (Pecularities of the Management Farmers' Farm as Business Organization). Management theory and studies for rural business and in-frastructure development, Vol. 14 (3), pp. 57-62. [In Lithuanian]

25. Rizov, M. 2005. Rural development under the European CAP: The role of diversity. The Social Science Journal, Vol. 42, Iss. (2), pp. 621-628. https://doi.org/10.1016/j.soscij.2005.09.003

26. Treinys, M. 2001. Agrarinès politikos problemų ir jų sprendimų būdų I-oje ir II - oje Lietuvos Respublikoje palyginimas (Comparison of the raised and solved Problems of Agrarian Policy during the 1th and the 2th historical period of the Independent Republic of Lithuania). Tarptautinès mokslinès konferencijos straipsnių rinkinys „Nepriklausomos Lietuvos žemès ūkio plètros dešimtmečiai"(Proceedings of the International Scientific Conference "Decades of Agricultural Development in Independent Lithuania"), pp. 95-105. [In Lithuanian]

27. Ūkių veiklos rezultatai (ŪADT tyrimo duomenys) 2015, 2010, 2005 (FADN survey results 2015, 2010, 2005). 2016, $2011,2006$. Lietuvos agrarinès ekonomikos institutas, Vilnius. [In Lithuanian]

28. Vidickienè, D., Melnikienè, R., Gedminaitė-Raudonè, Ž. 2013. Inovacijų diegimo Lietuvos ūkininkų ūkiuose motyvai ir barjerai (Motives and Barriers of using Innovations by Lithuanian Farmers). Management theory and studies for rural business and infrastructure development. 1, pp. 140-149. (In Lithuanian)

29. Vidickienè, D., Melnikienè, R. 2014. Kaimo politikos evoliucija (Rural Policy Evolution). Lietuvos agrarinès ekonomikos institutas. Vilnius. [In Lithuanian]

30. Zaleckienè, J. 2015. Ūkininko ūkio diversifikacijos sprendimo prièmimas (Farmer‘s Farm Diversification decision making). Daktaro disertacija (Doctoral Dissertation). Aleksandro Stulginskio universitetas. Akademija. [In Lithuanian]

31. Zaleckienè, J. 2008. Ūkininkų ūkių veiklos diversifikacijos ịgyvendinimo paskatos ir trikdžiai Management theory and studies for rural business and in-frastructure development, Vol. 15(4), pp. 208-217. [In Lithuanian]

32. Zimmermann, A., Heckelei, T., Dominquez, I. P. 2009. Modelling farm structural change for integrated ex-ante assessment: review of methods and determinants. Environmental science \& Policy, Vol. 12, pp. 601-618. https://doi.org/10.1016/j.envsci.2009.01.014 
33. Lietuvos kaimo pletros 2007-2013 metų programos statistika (Statistics of the Lithuanian Rural Development Program for 2007 2013). 2016. Available at https://www.nma.lt/index.php/parama/lietuvos-kaimo-pletros-20072013-mprograma/statistika/8801\#res (Accessed on 13/06/2017).

34. Žemės rinkos sektoriaus apžvalgos (Land Market Sector Reviews). Available at https://www.vic.lt/?mid=151\&id=18914 (Accessed on 02/06/2017) 